ROCZNIKI HUMANISTYCZNE

Tom LXVIII, zeszyt 2 - 2020

DOI: http://dx.doi.org/10.18290/rh20682-10

TOMISŁAW GIERGIEL

\title{
STAROPOLSKA LIBER BAPTISATORUM JAKO EDYCJA (STAN BADAŃ, METODY, POSTULATY)
}

Księgi ochrzczonych okresu staropolskiego są często jedynym źródłem wzmiankującym osoby przed osiągnięciem dojrzałości. Następnym tego typu źródłem mogą być Księgi ślubów, ale w przypadku zgonu w wieku przedmałżeńskim metryka chrztu pozostaje unikatowym śladem po jednostce osobie ochrzczonej. Oprócz usytuowania dziecka w rodzinie, wśród rodzeństwa, poprzez wzmiankowanie rodziców chrzestnych oraz ich pochodzenia, ukazują zaplecze materialne i opiekuńcze dziecka, jego relacje kulturowe, religijne, międzystanowe i sąsiedzkie. Metryki precyzyjnie wyliczają urodzenia bliźniąt oraz dzieci pozamałżeńskie. Zachowana w zasobie archiwalnym rejestracja metrykalna od przeszło wieku służy wielu celom naukowym. Zarówno o szerokim znaczeniu, ale też $\mathrm{w}$ zakresie mikrohistorii ${ }^{1}$. Przede wszystkim treść metryk daje ogromny zasób informacji demograficznej².

Wydawanie drukiem ksiąg metrykalnych, rozpoczęte kilkanaście lat temu, przyczynia się do ochrony tych źródeł archiwalnych, udostępnienia i upowszechnienia ich treści. Wśród tych inicjatyw znajdują się edycje Ksiag

Dr hab. TomisŁaw Giergiel - Uniwersytet Marii Curie-Skłodowskiej w Lublinie, Wydział Humanistyczny, Instytut Historii, Katedra Archiwistyki i Nauk Pomocniczych Historii; adres do korespondencji — e-mail: tomislaw@poczta.umcs.lublin.pl; ORCID: https://orcid.org/0000-00033335-8810.

${ }^{1} \mathrm{O}$ wartościach informacyjnych metryk kościelnych zob. K. DoBRowolsKI, Znaczenie metryk kościelnych dla badań naukowych, „Rocznik Towarzystwa Heraldycznego” 5 (1920), s. 90110, a także C. KUKLO, Staropolska rejestracja metrykalna ślubów, chrztów i pogrzebów w warsztacie badawczym historyka, w: Człowiek w teatrze świata. Studia o historii i kulturze dedykowane Profesorowi Stanisławowi Grzybowskiemu z okazji osiemdziesiatych urodzin, red. B. Popiołek, Kraków 2010, s. 38-52.

${ }^{2}$ I. GieyszTorowa, Wstęp do demografii staropolskiej, Warszawa 1976, s. 200; C. KuKLo, Demografia Rzeczypospolitej przedrozbiorowej, Warszawa 2009, s. 91-129. Przykład opracowania monograficznego: E. PIASECKI, Ludność parafii bejskiej (woj. kieleckie) w świetle ksiag metrykalnych z XVIII-XX w. Studium demograficzne, Warszawa 1990. 
ochrzczonych. Warto poddać je analizie, gdyż poza wyżej zasygnalizowanymi informacjami przy prowadzeniu tego typu rejestracji obowiązywał najszerszy formularz, który przewidywał przy opisie każdego chrztu odnotowanie do sześciu osób. Oczywiście liczba ksiąg wydanych drukiem w stosunku do zachowanych jest znikoma, ale można założyć, że ruch edytorski tego rodzaju dopiero się rozpoczyna (zauważalny jest dynamiczny wzrost zainteresowania tego typu publikacjami). Ogłoszenie zarówno katalogu tych edycji, jak i uwag na ich temat o charakterze nie tylko krytycznym, ale również postulatywnym i metodycznym może być również przydatne kolejnym wydawcom.

$\mathrm{Na}$ początku należy wyjaśnić, że określenie „edycja” rozumiemy jako pracę edytorską, która stara się wiernie oddać treść źródła poprzez wydanie go drukiem oraz zaopatrzona jest $\mathrm{w}$ aparat naukowy. Takie wydawnictwa można nazwać edycjami klasycznymi lub naukowymi, choć - jak się okaże nie wszystkie edycje drukowane na takie miano zasługują. Zadania udostępnienia i upowszechnienia treści rejestracji metrykalnej realizuje się współcześnie nie tylko w formie drukowanej, ale także innymi metodami, np. poprzez tzw. indeksację, która w większości przypadków obejmuje wiek XIX i początek wieku XX, czyli akta stanu cywilnego. Tych działań nie można jednak nazwać edycjami naukowymi, choć podawane są elementy treści źródła, ale zazwyczaj ograniczone do danych osobowych. Są one często udostępniane w wersji nieoryginalnej pod względem językowym. Przykładem są tłumaczenia na język polski i standaryzacja form onomastycznych, wprowadzane do systemów wyszukiwawczych ${ }^{3}$. Ponadto żywiołowo rozwijająca się indeksacja nie zawiera aparatu krytycznego i nie mamy gwarancji prawidłowości odczytu źródła, przez co nie może służyć celom badawczym ${ }^{4}$. Spełnia ona jednak funkcje społeczne, zadawalając rzesze genealogów amatorów i przy okazji odciąża pracownie naukowe archiwów. Również digitalizacja, przy podaniu pełnego obrazu źródła, nie zawiera aparatu krytycznego, choć upowszechnia treść metryk.

Wracając do pierwszego ze wzmiankowanych sposobów wydawania metryk, czyli metody naukowej, należy zauważyć, że zazwyczaj stosuje się ją w omówionych tutaj edycjach ksiąg parafialnych z czasów przedrozbiorowych. W tytule tych wydawnictw najczęściej występują określenia Księgi

\footnotetext{
${ }^{3}$ K. WiŚNIEwSKI, Indeksacja akt stanu cywilnego w Oddziale w Pultusku Archiwum Państwowego m. st. Warszawy, „Rocznik Lubelskiego Towarzystwa Genealogicznego” 3 (2011), s. 188.

${ }^{4}$ R. JOP, Uwagi problemowe o sposobie wydawania metryk parafialnych i innych formach ich udostepniania (tezy referatu), ,,Rocznik Polskiego Towarzystwa Heraldycznego”. Nowa Seria 11 (22) (2012), s. 55-59.
} 
metrykalne albo Metryki (ewentualnie w wersji łacińskiej), lecz poprawnie wydane metryki zamieszczone zostały również w książkach T. Wilczewskiego zatytułowanych Mieszkańcy parafii Pręgowo $w$ drugiej połowie XVII wieku ${ }^{5}$ oraz Metrykalna baza danych parafii Żukowo ${ }^{6}$.

W całości, w postaci wydawnictw zwartych, zostały wydane Księgi ochrzczonych z parafii w Radomsku ${ }^{7}$, Radomiu (dwie parafie) ${ }^{8}$, Wojniczu', Dmeninie $^{10}$, Tuchowie ${ }^{11}$, Przyrowie ${ }^{12}$, Ćmielowie ${ }^{13}$, Łęcznej $^{14}$, Skibniewie-

${ }^{5}$ T. WILCZEwSKI, Mieszkańcy parafii Pręgowo $w$ drugiej połowie XVII wieku, cz. 1: Źródła, Gdańsk 2012, s. 150-224; TENŻE, Metrykalna baza danych parafii Pręgowo 1711-1750, cz. 2: Źródta, Gdańsk 2013, s. 452-554. Zob. również: TENŻE, Mieszkańcy parafii Pręgowo $w$ drugiej połowie XVII wieku, cz. 2: Źródła, Gdańsk 2016, TENŻE, Mieszkańcy parafii Pręgowo w drugiej połowie XVII wieku, cz. 3: Rodziny i osoby, Gdańsk 2018.

${ }^{6}$ T. WiLCZEwsKi, Metrykalna baza danych parafii Żukowo, 1608-1700, cz. 1: Źródła, Gdańsk 2014, s. 419-541; TENŻE, Metrykalna baza danych parafii Żukowo 1701-1750, cz. 2: Źródła, Gdańsk 2015, s. 454-565.

${ }^{7}$ T.A. NowaK, Księgi metrykalne parafii św. Lamberta w Radomsku, Cz. 2: Ksiega ochrzczonych z lat 1739-1779, Radomsko 2013 (Radomszczańska Biblioteczka Regionalna V); Cz. 3: Księga ochrzczonych z lat 1779-1796, Radomsko 2014 (Radomszczańska Biblioteczka Regionalna VII). Edycja części 3 dostępna w postaci cyfrowej na stronie internetowej PTH, oddział w Radomsku - http://www.pthradomsko.org/ (dostęp 01.09.2019).

${ }^{8}$ Księgi metrykalne kościołów radomskich z lat 1591-1795, Seria A: Metryki chrztów, t. I: Kościót św. Jana Chrzciciela 1597-1620, red. A. Szymanek, Radom 2004; t. II: Kościót św. Jana Chrzciciela 1621-1636, red. S. Piątkowski, Radom 2001; t. III: Kościót św. Jana Chrzciciela 1637-1660, red. S. Piątkowski, Radom 2002; t. IV: Kościól św. Wacława 1636-1696, red. S. Piątkowski, Radom 2002; t. V: Kościót św. Wacława 1697-1712, red. S. Piątkowski, Radom 2003; t. VI: Kościót św. Jana Chrzciciela 1661-1677, red. S. Piątkowski, Radom 2003; t. VII: Kościót św. Jana Chrzciciela 1678-1712, red. D. Kupisz, Radom 2010; t. VIII: Kościót św. Jana Chrzciciela 1713-1745, red. D. Kupisz, Radom 2012; t. IX: Kościót św. Jana Chrzciciela 1746-1771, red. D. Kupisz, Radom 2012; t. X: Kościót św. Jana Chrzciciela 1772-1795, red. D. Kupisz, Radom 2012; t. XI: Kościót św. Wacława 1713-1744, red. D. Kupisz, Radom 2014; t. XII: Kościót św. Wacława 1745-1783, red. D. Kupisz, Radom 2013; t. XIII: Kościót św. Wacława 1784-1795, red. D. Kupisz, Radom 2014. Recenzja t. I autorstwa W. Kowalskiego zamieszczona została w „Studiach Historycznych” 49/2 (2006), s. 239-240.

${ }^{9}$ Metryki kolegiaty św. Wawrzyńca w Wojniczu 1675-1784, t. I: Liber baptisatorum 16751712, wyd. A. Jaworska i J. Szymański, cz. 1 (Biblioteczka Historyczna - Towarzystwo Przyjaciół Ziemi Wojnickiej, t. 30), Wojnicz 2006; cz. 2 (Biblioteczka Historyczna - Towarzystwo Przyjaciół Ziemi Wojnickiej, t. 31); t. IV: Liber baptisatorum 1757-1776, wyd. T. Giergiel i J. Szymański, cz. 1 (Biblioteczka Historyczna - Towarzystwo Przyjaciół Ziemi Wojnickiej, t. 34), Wojnicz 2008; cz. 2 (Biblioteczka Historyczna - Towarzystwo Przyjaciół Ziemi Wojnickiej, t. 35); t. VIII: Liber baptisatorum 1777-1784, wyd. T. Giergiel, J. Szymański i B. Trelińska, Wstęp: R. Jop (Biblioteczka Historyczna - Towarzystwo Przyjaciół Ziemi Wojnickiej, t. 39), Wojnicz 2017. Zob. T. GIERGIEL, Nowy nurt w edytorstwie źródel historycznych. Metryki wojnickie, „Res Historica” 27 (2009), s. 181-185.

${ }^{10}$ A. KACZMAREK, Księgi metrykalne parafii Świętych Apostołów Szymona i Judy Tadeusza $w$ Dmeninie, [t.] I: Liber baptisatorum, copulatorum et mortuorum parochialis in Dmenin 16351679, Dmenin 2008; [t.] II: Liber baptisatorum, copulatorum et mortuorum parochialis in Dme- 
Podawcach ${ }^{15}$ oraz ze wspomnianego Pręgowa i Żukowa. Do tego katalogu włączamy edycje metryk chrztów z parafii w Smogulcu ${ }^{16}$, w Brusach ${ }^{17}$ oraz w Mstowie ${ }^{18}$, które zostały wydane w formie artykułów.

W rozważaniach uwzględniamy edycję najstarszej metryki cieszyńskiej z lat 1628-1641 z parafii pod wezwaniem Marii Magdaleny ${ }^{19}$. Choć Cieszyn

nin 1723-1788, Dmenin 2009; [t.] III: Liber baptisatorum, copulatorum et mortuorum parochialis in Dmenin 1755-1788, Dmenin 2012; [t.] IV: Liber baptisatorum, copulatorum et mortuorum parochialis in Dmenin 1788 -1825, Dmenin 2012. Recenzje poszczególnych tomów autorstwa T.A. Nowaka zamieszczone zostały na łamach „Zeszytów Radomszczańskich” 4 (2010), s. 393-396; 5 (2011), s. 333-334; „Rocznika Łódzkiego” 57 (2010), s. 251-254; 58 (2011), s. 277-278.

${ }^{11}$ Metryka chrztów parafii św. Jakuba Apostoła w Tuchowie (1764-1776), oprac. M. L. Krogulski (Materiały do dziejów Tuchowa, tom IV), Tuchów 2014. Edycja dostępna w Tuchowskiej Bibliotece Cyfrowej: http://www.tuchow.pl/files/Materialy_do_dziejow_Tuchowa4.pdf (dostęp: 01.09.2019).

${ }^{12}$ A. KaczmareK, Księgi metrykalne parafii Świętej Doroty DM w Przyrowie, [t.] II: Liber baptisatorum parochialis in Przyrów 1759-1796, Przyrów 2016.

${ }^{13}$ Libri metrices ecclesiae parochialis Cmieloviensis, wyd. J. Moniewski, t. 1, B1: Libri baptisatorum ecclesiae parochialis Cmieloviensis 1601-1667, Radom 2002; t. 2, B2: Liber baptisatorum ecclesiae parochialis Cmieloviensis 1667-1695, Radom 2002; t. 3, B3: Liber baptisatorum ecclesiae parochialis Cmieloviensis 1695-1719, Radom 2002; t. 4, B4: Liber baptisatorum ecclesiae parochialis Cmieloviensis 1719-1739, Radom 2002; t. 5, B5: Liber baptisatorum ecclesiae parochialis Cmieloviensis 1739-1758, Radom 2002; t. 6, B6: Liber baptisatorum ecclesiae parochialis Cmieloviensis 1758-1797, P. 1: 1758-1770, Radom 2002; t. 7, B7: P. 2: 1771-1791, Radom 2002; t. 8, B8: P.3: 1792-1797, Radom 2002; t. 9, B9: Liber baptisatorum ecclesiae parochialis Cmieloviensis 1797-1810 in rubricis, Radom 2002; t. 22, B10: Libri baptisatorum ecclesiae parochialis Cmieloviensis 1811-1825 in rubricis, Radom 2005.

${ }^{14}$ Metryki chrztów Parafii pw. Św. Marii Magdaleny w Lęcznej z lat 1598-1624 i 1694-1695, oprac. R. Jop (Fontes Lublinenses 8), Lublin 2016.

${ }^{15}$ L. NiePIEKŁo, Parafia Skibniew Podawce i jej mieszkańcy, t. 2: Metryki od XVII do XIX wieku, Skibniew-Podawce 2018.

${ }^{16}$ M. GóRnY, Metryki chrztów parafii smoguleckiej, cz. 1: Lata 1592-1618, „Genealogia” 5 (1995), s. 107-140; TENŻE, Metryki chrztów parafii smoguleckiej, cz. 2: Lata 1619-1652, „Genealogia" 6 (1995), s. 89-132.

${ }^{17}$ T. REMBALSKI, Metryki chrztów parafii bruskiej z lat 1643-1649, „Acta Cassubiana” 7 (2005), s. 221-274. Edycja dostępna w kolekcji cyfrowej bazhum.muzhp.pl - http://bazhum.muzhp.pl/ media//files/Acta_Cassubiana/Acta_Cassubiana-r2005-t7/Acta_Cassubiana-r2005-t7-s221-274/ Acta_Cassubiana-r2005-t7-s221-274.pdf (dostęp: 01.09.2019).

${ }^{1 \overline{8}}$ A. SzKLARZ-HaBrowSKI, Księga ochrzczonych parafii Wniebowzięcia Najświętszej Maryi Panny we Mstowie (1719-1759), „Rocznik Towarzystwa Genealogicznego Ziemi Częstochowskiej” 2 (2011), s. 265-421.

${ }^{19}$ Najstarsze metryki cieszyńskie. Księga metrykalna parafii pod wezwaniem Marii Magdaleny w Cieszynie z lat 1628-1641, wyd. I. Panic (Acta Historica Silesiae Superioris t. 18), Cieszyn 2006. Edycja cieszyńska nie jest odnotowana w Bibliografii polskiej demografii historycznej po 1945 roku, oprac. P. Łozowski, w: Struktury demograficzne rodziny na ziemiach polskich do potowy XX wieku. Przegląd badań i problemów, red. P. Guzowski, C. Kuklo, Białystok 2014, s. $157-389$. 
w tym czasie należał do Korony Czeskiej, to panowała w nim ostatnia Piastówna Elżbieta Lukrecja, pochowana w kościele, w którym ta metryka była spisywana. Oczywiście to wszystko nie upoważnia do nazwania tej metryki staropolską, ale jej edycja należy do dorobku polskiego edytorstwa, a co więcej - przynosi ona bardzo ciekawy materiał pod względem językowym w odróżnieniu do metryk staropolskich spisywanych w języku łacińskim metryki cieszyńskie są spisane językiem, jakim posługiwała się rejestrowana ludność. Jak zauważył wydawca tej księgi, był to w przeważającej mierze język polski ${ }^{20}$.

Można zauważyć wielką różnorodność w sposobie tytułowania tego typu wydawnictw, co ma wpływ na ich obieg naukowy. Trudności przy opisie bibliograficznym sprawia wydana w Wydawnictwie Małonakładowym Jerzego Moniewskiego edycja ksiąg z Ćmielowa koło Ostrowca Świętokrzyskiego (ręcznie numerowana, dostępna tylko w kilku bibliotekach) czy wspomniane publikacje T. Wilczewskiego, wydawane nakładem własnym w liczbie 30 egzemplarzy, dostępne jednak w wersji cyfrowej ${ }^{21}$. Nie zostały tutaj uwzględnione liczne przypadki cytowania pojedynczych lub krótkich sekwencji wpisów, częste w badaniach biograficznych i genealogicznych ${ }^{22}$, bądź edycje tzw. wypisów, traktujące metryki fragmentarycznie lub selektywnie ${ }^{23}$.

Z mapy miejscowości parafialnych, których Ksieggi ochrzczonych doczekały się edycji (ryc.1), wynika wniosek o ogromnym rozrzucie geograficznym tych przedsięwzięć. Może to wpłynąć w sposób interesujący na wnioski z ich analizy, z uwagi na brak wzajemnych inspiracji i ustalonych wzorów. Jedynie edycja radomszczańska, dmenińska, mstowska i przyrowska prezentują zbliżony model wydania. Księgi będące podstawą tych edycji są przechowywane w Archiwum Archidiecezji Częstochowskiej im. ks. Walentego Patykiewicza w Częstocho-

\footnotetext{
${ }^{20}$ Tamże, s. 9-10.

${ }^{21}$ W zasobach Pomorskiej Biblioteki Cyfrowej (dostęp: 01.09.2019):

- publikacje dotyczące Pręgowa (por. przyp. 5): http://pbc.gda.pl/dlibra/docmetadata? $\mathrm{id}=19559 \&$ from $=\&$ dirids $=1 \&$ ver_id $=\& l p=6 \& Q I=$ http://pbc.gda.pl/dlibra/docmetadata? $\mathrm{id}=29642 \&$ from $=\&$ dirids $=1 \&$ ver_id=\&lp=5\&QI= http://pbc.gda.pl/dlibra/docmetadata? $\mathrm{id}=57640 \&$ from $=\&$ dirids $=1 \&$ ver_id=\&lp=1\&QI= http://pbc.gda.pl/dlibra/docmetadata? $\mathrm{id}=70474 \&$ from $=\&$ dirids $=1 \&$ ver_id=\&lp=9\&QI=

- publikacje dotyczące Żukowa (por. przyp. 6): http://pbc.gda.pl/dlibra/docmetadata?id=35767\&from=\&dirids=1\&ver_id=\&lp=2\&QI= http://pbc.gda.pl/dlibra/docmetadata? $\mathrm{id}=45464 \&$ from $=\&$ dirids $=1 \&$ ver_id $=\& 1 \mathrm{l}=3 \& \mathrm{QI}=$

${ }^{22}$ Na przykład: S. MaKAREwICZ, Cztery metryki Kazimierza Pułaskiego, „Archiwa, Biblioteki i Muzea Kościelne" 70 (1998), s. 237-245.

${ }^{23}$ Na przykład: Metryki szlachty ewangelickiej parafii Skoki i Rejowiec - wypisy, wyd. P.M. Dziembowski, „Gens” 8 (2003/2004), s. 77-98; Metryki szlachty parafii ewangelicko-reformowanej w Orzeszkowie - wypisy, wyd. P.M. Dziembowski, „Gens” 9 (2005/2006), s. 105-138; Metryki szlachty parafii ewangelicko-reformowanej w Waszkowie - wypisy, wyd. P.M. Dziembowski, ,Gens” 10 (2007/2008), s. 121-132.
} 
wie. Część tych inicjatyw ma charakter amatorski, a wśród wydawców przeważają regionaliści ${ }^{24}$. Brak zdecydowanej przewagi pracowników naukowych należy wytłumaczyć czasochłonnymi względami tego typu pracy i niesatysfakcjonującej parametryzacji wydawnictw źródłowych.

1. Mapa miejscowości parafialnych, których Księgi ochrzczonych doczekały się edycji.

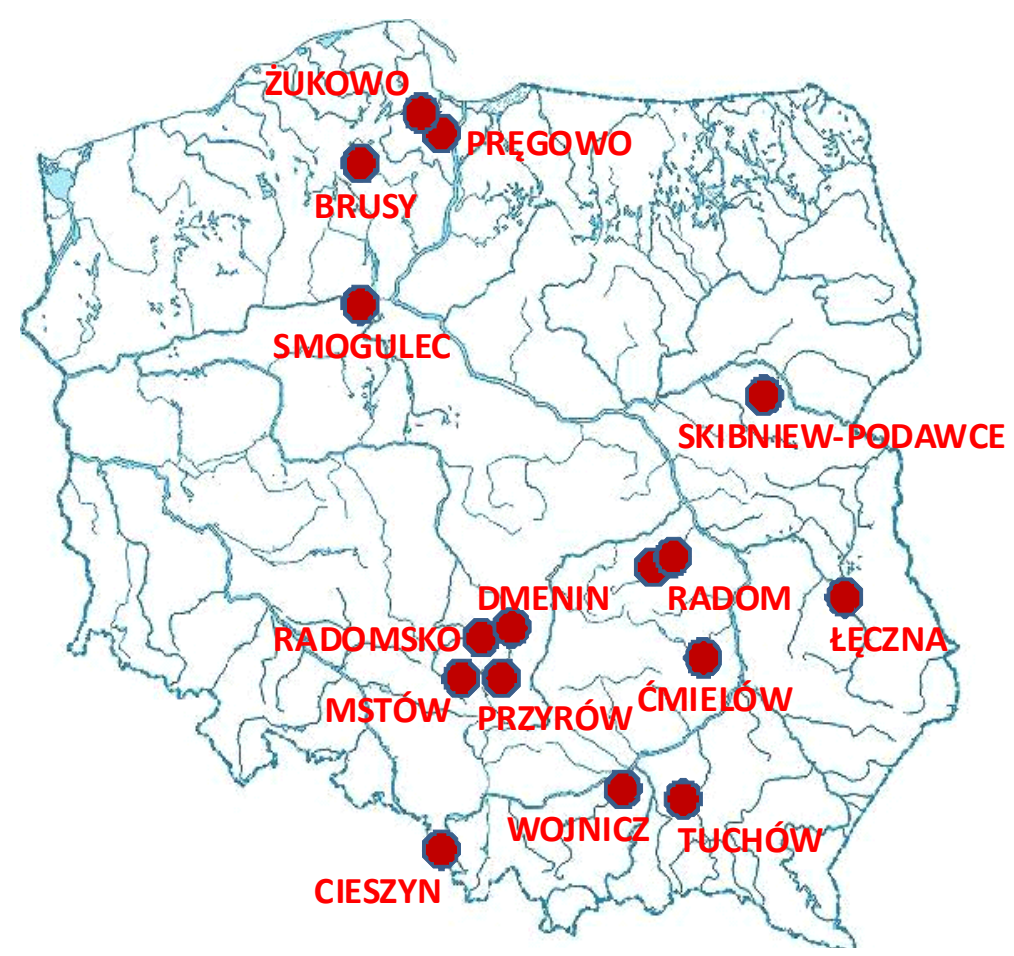

Zestawienie zawartości poszczególnych edycji Ksiag ochrzczonych z uwagi na chronologię i liczbę wpisów przedstawia Tabela 1.

Stan zachowania oraz konsekwencja wydawców pozwoliły w niektórych przypadkach na edycje rejestracji sięgającej kilku stuleci: w parafii ćmielowskiej, dmenińskiej i radomskiej. Najstarsze wydane metryki pochodzą ze Smogulca, ale niewiele od nich odbiega pod tym względem edycja łęczyńska i radomska. Wojnicka, ćmielowska i dmenińska objęły nie tylko metryki staropolskie, ale również okres bezpośrednio po objęciu miejscowości parafialnych zaborami (dwie ostatnie aż do 1825 r.). Uwzględniamy je w rozważaniach,

\footnotetext{
${ }^{24} \mathrm{Z}$ uwagi na tę sytuację niewykluczone jest, że istnieją wydania, które nie trafiają do bibliotek i nie występują w obiegu naukowym.
} 
Tabela 1.Zestawienie zawartości poszczególnych edycji Ksiąg ochrzczonych z uwagi na chronologię i liczbę wpisów.

\begin{tabular}{|c|c|c|c|}
\hline LP. & MIEJSCOWOŚĆ PARAFIALNA & DATY GRANICZNE & LICZBA WPISÓW/CHRZTÓW \\
\hline 1. & Brusy & $1643-1649$ & 229 \\
\hline 2. & Cieszyn & $1628-1641$ & wpisy nienumerowane \\
\hline 3. & Ćmielów & $\begin{array}{l}1601-1629,1631,1638,1654-1660, \\
1662,1665-1685,1687-1825\end{array}$ & wpisy nienumerowane \\
\hline 4. & Dmenin & $1635-1674,1723-1812,1816-1825$ & 3.642 \\
\hline 5. & Łęczna & $1598-1624,1694-1695$ & 1.269 \\
\hline 6. & Mstów & $1719-1759$ & wpisy nienumerowane \\
\hline 7. & Pręgowo & $1658,1665-1751$ & 5.115 \\
\hline 8. & Przyrów & $1759-1796$ & 2.332 \\
\hline 9. & Radom - parafia św. Jana Chrzciciela & $1597-1795$ & 9.173 \\
\hline 10. & Radom - parafia św. Wacława & $1636-1795$ & 5.160 \\
\hline 11. & Radomsko & $1739-1796$ & 8.761 \\
\hline 12. & Skibniew-Podawce & $1601-1903(!)$ & wpisy nienumerowane \\
\hline 13. & Smogulec & $1592-1652$ & 1.286 \\
\hline 14. & Tuchów & $1764-1776$ & 1.662 \\
\hline 15. & Wojnicz & $1675-1712,1757-1784$ & 9.540 \\
\hline 16. & Żukowo & $1608-1700$ & 7.483 \\
\hline
\end{tabular}

gdyż wydawnictwa te mogą przynieść interesujące obserwacje ze względu na zebranie materiału źródłowego, który powstawał pod rządami różnych norm i form państwowości (tytuły dwóch ostatnich tomów edycji ćmielowskiej zaopatrzone są $\mathrm{w}$ adnotację in rubricis) ${ }^{25}$. Niestety nie da się tego powiedzieć o edycji metryk z parafii Skibniew-Podawce, doprowadzonej aż do 1903 roku, o charakterze jednak wyłącznie wykazów osób urodzonych (oraz ich rodziców biologicznych oraz chrzestnych). W pozostałych przypadkach edycji krytycznych ich zakres zdeterminowany zachowaniem i dostępnością wydawanych ksiąg. Porównanie pod względem liczby wpisów na ogół nie

${ }^{25}$ Poza naszym zainteresowaniem są edycje obejmujące rejestrację metrykalną prowadzoną w całości pod rządami państw zaborczych, które jednak warto tutaj odnotować, np. Księga chrztów parafii radzionkowskiej z lat 1811-1850, oprac. Z. Kwaśny („Acta Universitatis Wratislaviensis", Historia, nr 131), Wrocław 1997; Liber natorum [parafii Ochotnica Dolna], t. 1: 1784-1820, oprac. ks. J. Urbaniak, Tarnów 2016. 
nastręcza trudności z uwagi na ich numerowanie przez wydawców, co jest praktyką zrozumiałą. Biorąc pod uwagę to kryterium (liczbę wpisów), na pierwszym miejscu należy wymienić edycję radomską i wojnicką, z kolei najszczuplejsze są metryki wydane w formie artykułów, czyli smogulecka i bruska. W edycji dmenińskiej, przyrowskiej i mstowskiej numerowanie zostało wprowadzone tylko w obrębie poszczególnych lat, ale we wstępie dwóch pierwszych podano liczbę wszystkich chrztów. Jedynie wydawcy metryk cieszyńskich, skibniewskich i ćmielowskich w ogóle nie nadali numeracji poszczególnym wpisom, co utrudnia korzystanie i cytowanie. Pierwsze dwie $\mathrm{z}$ tych edycji nie zawierają żadnego podsumowania liczby wpisów, ale w ćmielowskiej zamieszczono tabele zawierające liczbę chrztów w poszczególnych miesiącach.

Liczba wpisów, które - jak widać - są numerowane w różny sposób, zazwyczaj nie odpowiada liczbie udzielonych chrztów, gdyż w księgach trafiały się też wpisy niechrzcielne, nieurzędowe i adnotacje, w edycjach zazwyczaj również objęte numeracją (np. podliczenia liczby chrztów, treść dokumentów, wpisy o charakterze kronikarskim, informacje o wizytacjach generalnych i dziekańskich, rejestracja udzielania innych sakramentów niż chrzty, treść modlitw, wykazy bierzmowanych, inwentarze gospodarcze i inne notatki). Ukazują one metryki jako źródło historii wydarzeniowej, zresztą wykorzystywane w tym charakterze w nikłym stopniu ${ }^{26}$. Niektórzy wydawcy wyodrębnili tego rodzaju wpisy i zestawili oraz ponumerowali je osobno ${ }^{27}$. Osobnym problemem są chrzty bliźniąt wpisywane w jednym wpisie. Pomimo tego liczba wpisów jest bardzo zbliżona do liczby udzielonych chrztów (różnica wynosi ok. 1\%). Kilka edycji zawiera w jednym woluminie (tomie) również serie wpisów innych aktów: małżeństw czy zgonów, co było zdeterminowane faktyczną ich obecnością w księdze ochrzczonych (albo założeniem i prowadzeniem $\mathrm{w}$ parafii jednej księgi w celu rejestracji tych wszystkich wydarzeń $)^{28}$. Poszczególne woluminy (tomy) edycji zazwyczaj odpowiadają pod względem zawartości wydawanym księgom metrykalnym. W przypadku edycji pręgowskiej i żukowskiej mamy do czynienia z sytuacją odwrotną - tu w poszczególnych tomach edycji ogłoszono drukiem wpisy z kilku ksiąg ochrzczonych.

\footnotetext{
${ }^{26}$ Przykład wykorzystania edycji wojnickiej: W. KrawczuK, P. MiodunKA, K. NABiAŁeK, Dzieje Wojnicza od XVI do XVIII wieku, Wojnicz 2009, s. 384.

${ }^{27}$ Dmenin, Pręgowo, Żukowo.

${ }^{28}$ Cieszyn, Dmenin, Pręgowo, Żukowo.
} 
Fakt przywołania instrukcji wydawniczych przez wydawców ${ }^{29}$ nie implikuje w rzeczywistości stosowania się do tych instrukcji. Z drugiej strony niektórzy wydawcy, powołujący się na instrukcje, dokonują edycji w sposób poprawny, stosując trafne metody pracy poprzez analogię $\mathrm{z}$ innymi edycjami (co jest widoczne np. w edycji tuchowskiej, której wydawca znał edycję wojnicką) $)^{30}$. W związku $\mathrm{z}$ tym stopień wierności oddania treści źródła w edycjach metryk chrztów jest zróżnicowany. Tylko wydawcy wojnickich, cieszyńskich, ćmielowskich, tuchowskich i łęczyńskich metryk chrztów podali pełny oryginalny tekst in extenso, bez skrótów i uproszczeń, w formie narracyjnej odpowiadającej zeznaniom szafarza chrztu.

Oprócz pięciu podanych wyżej edycji z tekstem in extenso wszystkie pozostałe wydania Ksiag ochrzczonych podają ich treść, w różnym stopniu odchodząc od oryginału - w postaci tłumaczeń, regestów, wypisów, ekstraktów, wyciągów, wypisów (wydawcy stosują wymiennie różne określenia, choć nie są one tożsame), również rozkładając treść w tworzonych przez siebie tabelach. W każdym razie są to prace o mniejszym lub większym stopniu selektywności materiału „pozaosobowego”. Wydawcy tłumaczą te zabiegi tym, że wydanie pełnego tekstu zwiększałoby objętość pracy, byłoby zbyt hermetyczne w odbiorze oraz możliwe do wykorzystania tylko przez wąską grupę specjalistów. Wydawcy edycji radomskiej przyznają, że w konsekwencji należy ich pracę uznać za „popularnonaukową"31. Wobec faktu ogłoszenia drukiem kwintesencji zawartości rejestracji metrykalnej dylemat, czy mamy do czynienia z wydaniem, czy z opracowaniem materiału źródłowego, schodzi na dalszy plan, choć podniesiono, że metoda edycji radomskich uniemożliwia poznanie metrykalnej rzeczywistości „świata przodków”, nie mówiąc o zatarciu charakterystycznej zmienności pracy kancelarii ${ }^{32}$.

Z kolei metodę wydania tekstu in extenso może spotkać zarzut wprowadzania do edycji powtarzających się elementów formularza, „zabierających tylko miejsce" w wydaniu drukowanym. Wydaje się, że korzyść, którą się uzyskuje w przypadku opuszczenia tych elementów, czyli zmniejszenie edy-

\footnotetext{
${ }^{29}$ Brusy, Cieszyn, Wojnicz. Wydawcy powołują się na Instrukcję wydawniczq dla źródet historycznych od XVI do połowy XIX wieku, red. K. Lepszy, Wrocław 1953, ale także na inne instrukcje.

${ }^{30}$ Wydawca edycji tuchowskiej szeroko wykorzystał edycję wojnicką w innej własnej pracy: M.L. KROGULSKI, Rodowody mieszczan wojnickich, t. 1-4, Wojnicz 2006-2011.

${ }^{31}$ S. PIĄTKOWSKI, Wprowadzenie, w: Księgi metrykalne kościołów radomskich z lat 1591-1795, Seria A: Metryki chrztów, t. I: Kościót św. Jana Chrzciciela 1597-1620, red. A. Szymanek, Radom 2004; t. II: Kościót św. Jana Chrzciciela 1621-1636, red. S. Piątkowski, Radom 2001, s. 6.

${ }^{32}$ Tak K. Górna w recenzji tomów II, III, IV, V i VI edycji metryk radomskich - zob. „Genealogia” 17 (2005), s. 155.
} 
cji o kilkanaście stron, jest niewielka i niewarta stosowania. Nie wszystkie elementy formularza nic nie wnoszą i są niepoznawcze naukowo. Mówią o praktyce kancelaryjnej czy stosowaniu się do instrukcji i innych norm. Mniejszą wagę mają powtarzające się określenia, jak stwierdzenia kończące pierwsze zdanie i zaczynające drugie zdanie wpisu, które często brzmiało: „...coniugum legitimorum. Patrini fuerunt...” Elementem formularza były również kwalifikatory (predykaty określające pochodzenie stanowe rodziców biologicznych i chrzestnych), które odgrywają wielką rolę w badaniach społecznych, co jest respektowane przez wydawców edycji naukowych w odróżnieniu od badaczy biorących udział w indeksacji internetowej.

Rzadko stosuje się metodę wydania drukiem wraz z pełną digitalizacją metryk, jak ma to miejsce w edycji dmenińskiej ${ }^{33}$. Może ona jednak pogodzić potrzeby czytelnika niewprawionego i tego, który potrafi samodzielnie odczytywać rękopis. W „świat przodków”, a tym samym w świat trudności edytorskich mogłyby wprowadzać chociażby sondażowe reprodukcje zasadniczych czy instruktywnych stron poszczególnych ksiąg. Reprodukcje metryk - często w przypadkowych miejscach - występują w większości edycji (oprócz ćmielowskiej, radomszczańskiej, mstowskiej i skibniewskiej), lecz bardzo wyrywkowo i fragmentarycznie. Incydentalnie prezentowane są podobizny stron tytułowych ksiąg, poszczególne wpisy lub fragmenty stron edycji. Jedynie wydawca edycji cieszyńskiej obok wpisów oddanych drukiem paralelne reprodukował kilka przykładów wpisów z oryginału. Odwrotną i szczególną sytuacją jest nieprofesjonalne wydanie w formie zwartej fotografii (skanów) metrykalnego materiału źródłowego, czego dokonano w Suwałkach ${ }^{34}$. Wydawnictwo to nie zasługuje jednak na włączenie do katalogu tutaj omawianych edycji, gdyż tekst źródła nie został omówiony naukowo ani oddany drukiem. Jedynym przejawem jego opracowania są reprodukowane, sporządzone odręcznie (!) i częściowo błędnie, czego nie ukrywa wydawca (!), spisy osób ochrzczonych i zawierających związek małżeński.

Innym problematycznym zjawiskiem jest wpisywanie przez wydawców elementów wpisów (lub całych wpisów) do edytowanych tabel ${ }^{35}$. Jak wiadomo, rubryki pojawiają się w księgach metrykalnych dopiero w okresie za-

\footnotetext{
${ }^{33}$ Do t. II dołączona została płyta DVD ze skanami metryk.

${ }^{34}$ Metryki chrztów i ślubów od 1715 r. do 1765 r. oraz zgonów od 1763 r. do 1765 r. przechowywane $w$ archiwum parafii pod wezwaniem św. Aleksandra $w$ Suwałkach, t. 1-2, zebr. i przygot. do dr. S. Cieślukowski; kopie wykonał L. Sobolewski, Białystok 2016 [tytuł okładkowy: Metryki suwalskie].

${ }^{35}$ Dmenin, Przyrów, Pręgowo, Radomsko.
} 
boró $\mathrm{w}^{36}$ i zastosowanie metody tabelarycznej w edycjach dla wcześniejszego materiału źródłowego może sugerować odzwierciedlenie jego kompozycji oryginalnej. W konsekwencji będzie to mylące dla odbiorcy, który uzna, że jest to wierne oddanie formy prowadzenia metryk. Z kolei oryginalny wojnicki materiał tabelaryczny został oddany w edycji formą jednolitych wpisów, nawiązujących do formularza trydenckiego. Składające się na niego informacje pochodzą z różnych rubryk tabeli. Wiążą je łączniki dodane od wydawców w nawiasach kwadratowych, wskazujące na czynność (baptizavi infantem) i kolejnych uczestników aktu chrztu (parentes, patrini), nadając zapisowi jednolity charakter ${ }^{37}$.

Choć zalecenia edytorstwa naukowego nakazują edycję w języku oryginału, przy pracy nad metrykami (tak jak przy wyżej omówionym zjawisku ekstraktowania) pojawia się dylemat nakierowania wydawnictwa na tzw. szerokiego odbiorcę. Wydaje się, że prosta konstrukcja zapisu metrykalnego (składająca się, nie licząc nazw osobowych, z kilku łacińskich słów) nie powinno skłaniać edytora do tłumaczenia na język polski. Ponadto dla ułatwienia odbioru w kilku edycjach zamieszczony jest słowniczek łacińsko-polski ${ }^{38}$. Wybór języka wydania jest jednym z najtrudniejszych problemów, z uwagi na regionalnego odbiorcę, który często jest inicjatorem edycji, jego mecenasem i wydawcą, a także głównym czytelnikiem. Pomimo tych preferencji większość edycji dawana jest w języku oryginału ${ }^{39}$.

Omawiając działania wydawców służące objaśnieniu tekstu źródłowego i redakcję edycji oraz kreację aparatu krytycznego, należy zaznaczyć, że jest to praca, która wymaga spełnienia wysokich standardów zawartych $\mathrm{w}$ instrukcjach wydawniczych. Dzięki ich realizacji skorzystanie z edycji może zastąpić obcowanie $\mathrm{z}$ oryginałem, a także stworzyć funkcjonalne narzędzia umożliwiające zdobycie potrzebnej informacji bez konieczności dotarcia do księgi i odczytu (analizy) całej jej zawartości. Charakterystyka wydawanego źródła ma miejsce we wstępach do edycji, poprzedzanych często osobnymi wprowadzeniami. Poza nimi edycja dmenińska i przyrowska zawiera również

${ }^{36}$ B. KUMOR, Reforma metryk kościelnych w zaborze austriackim (1775-1788), w: Studia z historii gospodarczej $i$ demografii historycznej. Prace ofiarowane profesorowi Stanisławowi Hoszowskiemu w 70. rocznicę urodzin, red. J.M. Małecki, (Akademia Ekonomicznej w Krakowie, Zeszyty Naukowe, nr 70: 1974), Kraków 1975, s. 327-336; P. RACHWA£, Księgi metrykalne z czasów zaboru austriackiego $w$ archiwach parafialnych $w$ Lubelskiem - regulacje prawne, stan zachowania, „Rocznik Lubelskiego Towarzystwa Genealogicznego” 6 (2014), wyd. 2015, s. 306-325.

${ }^{37}$ R. JoP, Wstęp, w: Metryki kolegiaty św. Wawrzyńca w Wojniczu, t. VIII, s. 10.

${ }^{38}$ Dmenin, Pręgowo, Wojnicz, Żukowo.

${ }^{39}$ Łęczna, Brusy, Cieszyn, Ćmielów, Pręgowo, Smogulec, Tuchów, Wojnicz, Żukowo. 
osobne Podsumowania. Te narracyjne elementy opracowania edycji powinny mówić przede wszystkim o postaci zewnętrznej źródła, z pożądaną analizą bibliologiczną (kodykologiczną) księgi metrykalnej, uwzględniającą kwestię kompletności i kolejności wpisów i składek księgi oraz charakterystykę paleograficzną i identyfikację rąk pisarskich. Okazuje się, że dowolność wydawców jest w tym zakresie wielka, np. z edycji cieszyńskiej w ogóle nie dowiemy się, jaka jest konstrukcja wydanej księgi.

Następnie we wstępie do edycji powinna być zawarta informacja o jej zawartości wewnętrznej i zasadach wydania (zakres chronologiczny, zasięg terytorialny i układ wydawnictwa). Wielu wydawców stara się realizować te postulaty. Najszerszą informację otrzymujemy w edycji wojnickiej, radomskiej i łęczyńskiej, które wychodzą poza zalecenia instrukcji wydawniczych, zamieszczając szersze rysy dziejów parafii, rejestracji metrykalnej czy elementy interpretacji treści metryk, m.in. dotyczące chrztów prywatnych, konwersji, antroponomastyki, spraw społecznych czy stosowania prawa kościelnego. Wiele wstępów zawiera jednak tylko zdawkowe informacje na temat założeń edycji i jej podstawy rękopiśmiennej ${ }^{40}$. Najmniej dowiadujemy się o kryteriach wyboru podstawy wydania. Zapewne wynikają one z osobistych zainteresowań edytora, np. ujawnionych w edycji pęgowskiej i żukowskiej. Nie wiemy nic o kryteriach wyboru podstawy wydania edycji radomskiej, pomimo wieloletniego i wieloosobowego zaangażowania. Za jeden $\mathrm{z}$ najpilniejszych postulatów należy uznać ogłoszenie aktualizacji inwentarzy metrykalnych ksiąg staropolskich, co czyni się w niektórych archiwach kościelnych $^{41}$, a także dokończenie katalogowania ksiąg metrykalnych przechowywanych $\mathrm{w}$ archiwach parafialnych ${ }^{42}$. Wówczas kwestia wyboru podstawy wydania nabrałaby obiektywizacji i dokonywano by jej z naukową rozwagą.

Wstępy do edycji często nie omawiają elementów formularza, jego specyfiki, struktury, wariantów, ewolucji, odstąpień od jego schematu - zapewne wynika to $\mathrm{z}$ braku jego zrozumienia i niedowartościowania informacji w nim zawartej. W końcu, jeżeli się go lekceważy i pomija, otrzymujemy materiał wyabstrahowany z kontekstu historycznego i dyplomatycznego, ograniczony do przetłumaczonych na język polski danych osobowych. Taki charakter mają

\footnotetext{
${ }^{40}$ Tylko edycja skibniewska nie posiada jakiegokolwiek wstępu czy prezentacji podstawy źródłowej.

${ }^{41}$ W.P. WLAŹLAK, Inwentarz ksiag metrykalnych Archiwum Archidiecezji Częstochowskiej im. ks. Walentego Patykiewicza, „Rocznik Towarzystwa Genealogicznego Ziemi Częstochowskiej" 1 (2011), s. 11-580.

${ }^{42}$ P. RACHWAL, Staropolskie ksiegi metrykalne $w$ archiwach parafialnych archidiecezji lubelskiej, „Kwartalnik Historii Kultury Materialnej” 63 (2015), z. 4, s. 585-601.
} 
edycje dmenińska, przyrowska, radomszczańska, mstowska i skibniewska. Wydawcy dwóch ostatnich $z$ edycji pominęli nawet osobę szafarza, dlatego zawartość tych wydań zadowoli jedynie odbiorcę amatorskiego. Pod względem funkcji zbliżone są do indeksacji internetowej, a tytuły tych wydawnictw: Księgi metrykalne, Metryki czy Księga ochrzczonych są nadawane zbyt pochopnie i nieadekwatne do ich zawartości, która raczej zbiera i za pomocą różnych kryteriów grupuje materiał onomastyczno-genealogiczny ${ }^{43}$. Horyzont wydawniczy, czyli funkcje pracy, powinny być wyznaczone czytelnie: wysentytezowanie materiału genealogicznego czy odzwierciedlenie drukiem pełnego przekazu źródła historycznego i jego specyfiki. Aby uniknąć tych wątpliwości, należy we wstępie określić i uzasadnić przedmiot oraz cel wydawnictwa.

Kolejnym elementem aparatu krytycznego, objaśniającego tekst wydawanego drukiem źródła, są indeksy nazw osobowych, geograficznych oraz rzeczy, dawniej zwane skorowidzami. Również te elementy mają w praktyce wydawniczej niejednolity charakter i poziom naukowy (nawet $\mathrm{w}$ ramach jednej edycji - serii wydawniczej). Edycje: radomska, tuchowska, wojnicka i łęczyńska mają klasyczne alfabetyczne indeksy osobowe z odwołaniem do numeracji wpisów. Niektóre indeksy osobowe zawierają oprócz odwołania do numeru wpisu rozbudowane informacje o jednostce i jej krewnych. Nazwy osobowe zebrane w indeksach pierwszej części edycji pręgowskiej (jako Alfabetyczny wykaz nazwisk, również z objętych edycją metryk małżeństw i zgonów), bruskiej i pierwszego tomu radomskiej oddane są w brzmieniu źródła. W pewnym stopniu weryfikuje to przetłumaczony tekst główny edycji radomskiej. Ponadto indeks w edycji bruskiej grupuje mieszkańców poszczególnych miejscowości wchodzących w skład parafii, tworząc w istocie indeks geograficzno-osobowy. Aby odszukać daną jednostkę, należy wiedzieć, z jakiej miejscowości pochodziła (nie wystarczy wiedza, że należała do społeczności parafii). Takie rozwiązanie wymusza ułożenie osobnego zestawienia osób z miejscowości, które pozostają niezidentyfikowane. Nie powoduje to trudności przy korzystaniu pod warunkiem stosunkowo nielicznego zasobu danych, jaki występuje właśnie w Brusach. Podobne kryteria zastosował wydawca już znacznie obszerniejszych metryk dmenińskich i przyrowskich, lecz indeksy tam opublikowane, w formie tabelarycznej, zawierają

\footnotetext{
${ }^{43}$ Przykład adekwatnej tytulatury edycji tego typu Nazwiska ochrzczonych parafii Ostróg 1599-1652, w: Wykazy osób z akt parafialnych diecezji tuckiej do 1945 roku, [t. 1], oprac. W.W. Żurek, Lublin-Kielce 2004, s. 743-754. Nie uwzględniamy jej w niniejszym opracowaniu nie tylko z powodu selektywnej zawartości, ale przede wszystkim ze względu na podstawę wydania (maszynopis).
} 
przy imieniu i nazwisku wszystkie daty i fakty rejestrowane w innych metrykach, numerowane porządkowo w obrębie zestawianych miejscowości (co szacunkowo mówi o ich zaludnieniu). W wyniku benedyktyńskiej pracy wydawcy metryk, proboszcza parafii w Dmeninie, a następnie w Przyrowie, otrzymaliśmy zestawienie dostępnych danych o urodzeniu/chrzcie mieszkańca, czasie zawierania przez niego małżeństwa i jego daty śmierci/pogrzebu oraz pełnionych funkcji i stanu społecznego. Rzut oka na efekty tej pracy pozwala jednak stwierdzić, że bardzo rzadko udało się zgromadzić wszystkie zakładane informacje, co zapewne było skutkiem migracji poza parafię, poza tym brak odnotowań ślubów i zgonów wynikała z wysokiej śmiertelności małych dzieci. Niemniej jest to unikatowe zestawienie - w istocie quasi-biograficzne - kilku tysięcy mieszkańców wsi należących do dwóch okręgów parafialnych.

Wydawca metryk pręgowskich i żukowskich, oprócz wyżej wspomnianego Alfabetycznego wykazu nazwisk, do wszystkich tomów edycji ułożył zestawienia w układzie chronologicznym, określone jako Podstawowe bazy danych. Obejmują one oryginalne brzmienie imion i nazwisk wszystkich świeckich uczestników chrztów (i innych rejestrowanych wydarzeń) oraz przyporządkowują im osobne numery identyfikacyjne. Pomijając wiele szczegółów niezwykle „technicznych” rozwiązań opracowania tych metryk, można wyrazić obawę, czy ułatwią one korzystanie z edycji zarówno przez lokalną społeczność, jak i przez badaczy.

Pomimo że w edycji ćmielowskiej nie wprowadzono numeracji wpisów, zawiera ona indeks ochrzczonych, którego hasła odsyłają do wpisów identyfikowanych poprzez daty chrztów (ale również do numerów stron edycji i kolejnych wpisów umieszczonych na tej stronie). Indeks ten zawiera także imiona rodziców dziecka oraz oznaczenie miejscowości. Za kryterium jego ułożenia przyjęto nazwisko ojca ochrzczonego dziecka, podobnie jak w edycji pręgowskiej. Przy tworzeniu indeksów wydawcy w różny sposób radzą sobie z problemem odnotowania wyłącznie imienia osoby czy brakiem możliwości odczytu nazwiska. Niezwykle rozbudowana edycja ćmielowska zawiera osobne indeksy osób identyfikowanych jedynie poprzez imię, nazwisko matki oraz poprzez zawód (stan) ojca, a także zestawienie urodzonych z nieprawego łoża. Do edycji żukowskiej dołączony został spis członków rodzin muzyków klasztornych w latach 1608-1750 oraz wykaz 1305 nazwisk osób z lat 1608-1750 określanych w metrykach żukowskich jako nobilis, oba w porządku chronologicznym ${ }^{44}$.

\footnotetext{
${ }^{44}$ T. WILCZEWSKI, Metrykalna baza danych parafii Żukowo, 1608-1700, s. 17-31; TENŻE, Metrykalna baza danych parafii Żukowo 1701-1750, s. 14-63.
} 
Ostatnie $\mathrm{z}$ omówionych edycji w zakresie uporządkowania i zestawienia danych zawierają rozwiązania bardziej wyrafinowane - służące identyfikacji, ale też integralnego rozpoznania jednostek w całym kontekście rodzinnym i kościelnym. Pomimo wykształcenia technicznego wydawców edycji pomorskich i ćmielowskich oraz wdrożenia szeregu precyzyjnych narzędzi informatycznych, które często zasłaniają społeczno-dziejowe oblicze metryk, ich specyficzny aparat krytyczny powinien być poddany szerszej dyskusji oraz życzliwie przyjęty przez historyków i innych wydawców.

Nie wszyscy edytorzy przy tworzeniu indeksów nazw osobowych zmierzyli się z próbą identyfikacji ogromnej rzeszy osób. Uwaga ta dotyczy również wydawców, którzy zawodowo zajmują się źródłami historycznymi. Na stwierdzenie tożsamości osób o tym samym imieniu i nazwisku pozwalał często zapisany urząd, kwalifikator, pochodzenie miejscowe. Wobec jednak jednostek stanu chłopskiego, przy wąskim zasobie imion i nazwisk oraz braku pełnej stabilności nazw osobowych, nie zawsze to zadanie jest wykonalne, nawet dla wydawców znających kontekst dziejowy. Jako przykład rozwiązań metodycznych w tym zakresie można podać edycję wojnicką, w której wydawcy grupowali przypadki występowania osoby w roli rodzica oraz w funkcji chrzestnego, gdy występowały co najmniej dwie osoby o tym samym imieniu i nazwisku. Na więcej nie pozwalał charakter źródła i fakt nieodnotowywania tych jednostek przez inne przekazy.

Zakładając, że każdy metrykalny wpis o chrzcie zawiera na ogół informację o sześciu osobach (choć, jak wiadomo, powszechnie występują wahania w tym względzie), indeksy omawianych edycji zawierają identyfikację niemal 200 tysięcy jednostek (po koniecznych redukcjach, wynikających z wystąpień wielokrotnych), często połączoną z ustaleniem ich tożsamości, co ukazuje skalę uzyskanego materiału, w dodatku uchwytnego bibliograficznie, czego nie można powiedzieć o indeksacji internetowej. Tylko jednak wzorowo opracowane skorowidze mogą zastąpić kwerendę źródłową. Wszystkie trzy rodzaje indeksów zawiera jedynie edycja wojnicka i łęczyńska, a o poziomie opracowania tych edycji świadczą występujące tylko tam indeksy rzeczowe. Indeksy stanowią, jak widać, element niezwykle zindywidualizowany edycji ksiąg ochrzczonych. Zróżnicowanie metod tworzenia indeksów - mniej lub bardziej funkcjonalnych - pozwala na wybór optymalnych rozwiązań przyszłych edycji. Aktualnie edycje radomszczańska, pręgowska, żukowska, bruska i tuchowska są dostępne również w formie cyfrowej w Internecie - tworzy to zupełnie inne, właściwie dowolne, możliwości wyszukiwawcze, nieosiągalne w formie drukowanej, nawet najbardziej rozbudowanej. 
Edycje cieszyńska, smogulecka, mstowska, skibniewska oraz radomszczańska i żukowska w ogóle nie zawierają indeksów (choć dwie ostatnie mają funkcję wyszukiwania dzięki wersji cyfrowej). Wydawcy nie tłumaczą się zazwyczaj z tego uchybienia. Jedynie w edycji cieszyńskiej przeczytamy, że rezygnacja $\mathrm{z}$ opracowania indeksu była świadoma, $\mathrm{z}$ uwagi na ryzyko umieszczenia pod tym samym imieniem i nazwiskiem różnych osób. Wytłumaczenie to należy uznać raczej za uchylenie się wydawców od pracy pochłaniającej tyle czasu, co przygotowanie tekstu źródła. Wyżej omówione zostały różne sposoby rozwiązań tego problemu. Korzystanie z edycji bez indeksów wymaga czasu i cierpliwości, bezspornym jednak walorem pozostaje w dalszym ciągu odczyt i upowszechnienie treści źródła.

Inwencja wydawców niekiedy wychodzi poza instrukcje wydawnicze, czego przykładem są wielokrotnie wskazywane innowacje edycji pręgowskiej i żukowskiej. Tylko w edycji dmenińskiej zauważymy niewystępujący w oryginale dzień tygodnia przy każdej dacie dziennej chrztu (co umożliwiło wydawcy na zamieszczenie ciekawych wniosków o preferowanych w tej parafii dniach, w których udzielano chrztów), ale bez podania informacji, że ten element jest zrekonstruowany i pochodzi od edytora. Tylko czytelnik obeznany $\mathrm{z}$ formularzem rozpozna i zrozumie ten element jako wtręt wydawcy, ale wielu odbiorców błędnie uzna, że jest to element zapisu oryginału. Ten sam wydawca do edycji przyrowskiej nie wprowadził tego elementu. Umożliwia on rozpoznanie interesującego zjawiska kulturowego, lecz powinien być wyraźnie oznaczony jako nienależący do treści wydawanej metryki.

Przechodząc do dalszej analizy aparatu krytycznego, należy podkreślić, że celem osiągnięcia jak największej przejrzystości w wydawnictwie, wszystko co pochodzi od wydawcy, a więc np. tytuły i daty w nagłówku, należy drukować kursywą, sam zaś tekst źródłowy antykwą. Idąc za instrukcjami miejsce zniszczone i nieczytelne, należy uzupełnić nie zmieniając kroju druku (antykwą) i zaznaczyć ujęciem w nawiasy prostokątne z odsyłaczem wewnątrz nawiasu do przypisu informującego o rodzaju braku. Jeśli wydawca nie może uzupełnić miejsca zniszczonego, czy nieczytelnego, zaznacza je w nawiasach prostokątnych mniej więcej tylu kropkami, ilu liter brakuje. Brak całego wyrazu, większej ilości słów lub całych wierszy zaznacza się nawiasami prostokątnymi bez kropek z odsyłaczem wewnątrz nawiasu. W przypisie tekstowym podaje się rodzaj braku oraz w przybliżeniu liczbą liter, jaka mogłaby się tam pomieścici ${ }^{45}$. Są to jednak zasady stosowane

\footnotetext{
${ }^{45}$ Instrukcja wydawnicza dla źródel historycznych od XVI do połowy XIX wieku, red. K. Lepszy, Wrocław 1953, passim.
} 
przez wydawców metryk bardzo rzadko. Wydawcy raczej stosują własne reguły, nie zawsze zgodne z instrukcjami i praktyką edytorską. W przypadku wyabstrahowania materiału osobowego, czy jego tłumaczenia na język polski (a także w obu tych przypadkach jednocześnie) nie poznamy przebiegu procesu odczytu, nie dowiemy się czy źródło było czytelne i w jakim stanie zachowania się znajduje. W Wojniczu postarano się z kolei, aby część z trudnych do odczytu wpisów została zrekonstruowana w świetle podczerwonym, dzięki pomocy Wydziału Kryminalistyki Komendy Wojewódzkiej Policji w Lublinie.

Dzięki temu, że zapisy metrykalne w edycjach zaopatrzone są w szereg informacji, komentarzy, odniesień filologicznych, biograficznych i rzeczowych, pomagają rozeznać się w konkretnych kategoriach badawczych. Zastosowany w edycjach aparat krytyczny i jego treść stanowią znaczny dorobek, często niedoceniany w badaniach nad społeczeństwem staropolskim. Wzmiankowane treści są efektem pracy edytora nad źródłem podczas przygotowania go do druku, a więc badacza najbardziej zorientowanego w strukturze informacyjnej źródła, co podnosi wiarygodność zamieszczonego komentarza.

Komentarz niekiedy wychodzi poza ramy wskazywane $\mathrm{w}$ instrukcjach i przeradza się w wypisy $\mathrm{z}$ wydanego materiału albo jego analizę naukową. Najczęstszym rodzajem wypisywanych danych są informacje o szafarzach chrztu, formowane w zestawienie duchownych. Postarała się o nie (niekiedy z omówieniem) większość wydawców, oprócz edycji cieszyńskiej, bruskiej, wojnickiej i skibniewskiej. Dla kilku wydawców osobne zestawienie duchownych usprawiedliwiło nieujmowanie ich w edytowanych informacjach składających się na opis udzielanego chrztu bądź wykluczenie szafarzy z indeksów osobowych, co należy uznać za nieporozumienie. Nawet dla genealogów amatorów i regionalistów osoba duchownego udzielającego konkretnego chrztu ma znaczenie.

Wypisy dotyczą też zauważonych przez wydawców sytuacji szczególnych czy ciekawych. Wstępy zawierają czasem elementy interpretacji treści metryki w postaci krótkich analiz z dziedziny demografii, dziejów społecznych, historii lokalnego Kościoła czy antroponomastyki. Pełne zestawienie frekwencji wszystkich imion chrzestnych podają edycja dmenińska, łęczyńska, radomszczańska (dla III części) i ćmielowska (dla pierwszego tomu). W edycji wojnickiej i pręgowskiej zamieszczono mapy okręgów parafialnych. Obszar parafii był bowiem niewątpliwie czynnikiem źródłotwórczym rejestracji metrykalnej ${ }^{46}$. To

\footnotetext{
${ }^{46}$ P. RACHWAE, B. SzADY, Obszar parafii jako czynnik źródtotwórczy rejestracji metrykalnej $w$ dekanacie Kazimierz na przełomie XVIII i XIX wieku, „Przeszłość Demograficzna Polski” 38 (2016), nr 2, s. 35-72.
} 
jedynie przykłady wykorzystania danych zaczerpnięte z opracowań towarzyszących edycjom. Należy się jednak zastanowić, czy aparat naukowy stosowany w wydaniach Ksiag ochrzczonych powinien eksponować wszystkie wymienione wyżej problemy. $\mathrm{Z}$ drugiej strony bez pogłębionego wstępu i adekwatnego aparatu krytycznego oraz pomocniczego edycja ograniczy się tylko do zestawienia danych osobowych. Odpowiednio zastosowany aparat krytyczny odpowie na ciekawe pytania, wiele wnosząc do różnorodnych problemów badawczych. Polskie edycje Ksiag ochrzczonych reprezentują więc zróżnicowany poziom edytorski pod względem metodycznym. Podobny wniosek zapewne jest adekwatny do edycji innych rodzajów rejestracji metrykalnej, również zasługujących na rozważania metodyczne. Szereg edycji ujawnia swego rodzaju eksperymentowanie w zakresie metodycznym. Miejmy nadzieję, że to zestawienie i krytyka zakończy pierwszy etap w rozwoju edytorstwa metrykalnego. Wszelkie wątpliwości rozwiałaby instrukcja wydawania źródeł metrykalnych, jak inne instrukcje dedykowane konkretnym gatunkom źródeł (np. kronikom czy inskrypcjom) ${ }^{47}$. Gwarancja wysokiego poziomu edycji może również wynikać z zasad wydawniczych samodzielnie opracowanych, zastosowanych i ogłoszonych we wstępie do edycji przez edytora $^{48}$. W przeciwnym razie edycja będzie niewiarygodna i nie będzie służyć celom naukowym i społecznym. Instrukcja lub zbiór adekwatnych zasad mogłyby ukierunkować i wspierać prace edytorskie prowadzące do uzyskania szerszego obrazu rejestracji metrykalnej na ziemiach polskich ${ }^{49}$. Oprócz wyżej zasygnalizowanych postulatów należy zauważyć, że wiele $\mathrm{z}$ edycji przedstawionych $\mathrm{w}$ niniejszym artykule wykazuje brak zdecydowania, do jakiego rodzaju czytelnika chcą trafić. Niezwykle trudno wyważyć i pogodzić zadania służebne wobec ruchu genealogicznego i wobec nauki (dzieje i geografia Kościoła, nowożytna dyplomatyka, demografia historyczna).

Dokonując próby rekapitulacji dotychczasowych osiągnięć historiografii $\mathrm{w}$ zakresie rozwoju narzędzi badawczych wykorzystywanych w polskich edycjach Ksiag ochrzczonych, należy podkreślić, że wzbogacają naszą wiedzę na temat dziejów społecznych, kulturalnych, demograficznych i prawnohistorycznych w zaniedbanym naukowo obszarze wczesnej kategorii wieko-

${ }^{47}$ Z. BUdKOWA, M. FRIEDBERGOWA, B. KÜRBISÓwNA, Instrukcja dla wydawnictwa roczników polskich, „Studia Źródłoznawcze” 1 (1957), s. 182-184; Instrukcja wydawnicza dla źródet epigraficznych, oprac. J. Szymański, B. Trelińska, Lublin 2003.

${ }^{48}$ J. TANDECKI, K. KOPIŃSKI, Edytorstwo źródet historycznych, Warszawa 2014, s. 222.

${ }^{49}$ R. JoP, Metryki parafialne wyznania rzymskokatolickiego - stan wiedzy i potrzeby badawcze, w: Belliculum diplomaticum IV Thorunense. Dyplomatyka staropolska - stan obecny i perspektywy badań, red. W. Chorążyczewski, J. Tandecki, Toruń 2011, s. 157. 
wej osób ochrzczonych. Można śmiało powiedzieć, że te z omówionych edycji, które prezentują wysokie walory poznawcze, przyczyniają się do likwidacji anonimowości „najmłodszej” części zbiorowości ludzkiej.

\section{BIBLIOGRAFIA}

Bibliografia polska demografii historycznej po 1945 roku, oprac. Piotr Lozowski, w: Struktury demograficzne rodziny na ziemiach polskich do połowy XX wieku. Przeglad badań i problemów, red. Piotr Guzowski, Cezary Kuklo, Białystok: Instytut Badań nad Dziedzictwem Kulturowym Europy 2014.

Budkowa Zofia, Friedbergowa Maria, KÜRBISÓwna Brygida, Instrukcja dla wydawnictwa roczników polskich, „Studia Źródłoznawcze” 1 (1957), s. 182-184.

DoBrowolski Kazimierz, Znaczenie metryk kościelnych dla badań naukowych, „Rocznik Towarzystwa Heraldycznego" 5 (1920), s. 90-110.

GIERGIEL Tomisław, Nowy nurt w edytorstwie źródel historycznych. Metryki wojnickie, „Res Historica" 27 (2009), s. 181-185.

GieysZTorowa Irena, Wstęp do demografii staropolskiej, Warszawa: Państwowe Wydawnictwo Naukowe 1976.

GóRNY Marek, Metryki chrztów parafii smoguleckiej, cz. 1: Lata 1592-1618, „Genealogia” 1995, nr 5, s. 105-140.

GóRnY Marek, Metryki chrztów parafii smoguleckiej, cz. 2: Lata 1619-1652, „Genealogia” 1995, nr 6, s. 89-132.

Instrukcja wydawnicza dla źródet epigraficznych, oprac. Józef Szymański, Barbara Trelińska, Lublin: Wydawnictwo UMCS 2003.

Instrukcja wydawnicza dla źródeł historycznych od XVI do połowy XIX wieku, red. Kazimierz Lepszy, Wrocław: Ossolineum 1953.

JOP Robert, Metryki parafialne wyznania rzymskokatolickiego - stan wiedzy i potrzeby badawcze, w: Belliculum diplomaticum IV Thorunense. Dyplomatyka staropolska - stan obecny i perspektywy badań, red. Waldemar Chorążyczewski, Janusz Tandecki, Toruń: Wydawnictwo Naukowe UMK 2011.

JoP Robert, Uwagi problemowe o sposobie wydawania metryk parafialnych i innych formach ich udostęniania (tezy referatu), „Rocznik Polskiego Towarzystwa Heraldycznego”. Nowa Seria 11 (22) 2012, s. 55-59.

KacZmareK Antoni, Księgi metrykalne parafii Świętej Doroty DM w Przyrowie, [t.] II: Liber baptisatorum parochialis in Przyrów 1759-1796, Przyrów: Wydawnictwo i Poligrafia Kurii Prowincjalnej Zakonu Pijarów 2016.

KACZMAREK Antoni, Księgi metrykalne parafii Świętych Apostołów Szymona i Judy Tadeusza w Dmeninie, [t.] I: Liber baptisatorum, copulatorum et mortuorum parochialis in Dmenin 1635-1679, Dmenin: Wydawnictwo i Poligrafia Kurii Prowincjalnej Zakonu Pijarów 2008.

KaCZMAReK Antoni, Księgi metrykalne parafii Świętych Apostołów Szymona i Judy Tadeusza w Dmeninie, [t.] II: Liber baptisatorum, copulatorum et mortuorum parochialis in Dmenin 1723-1788, Dmenin: Wydawnictwo i Poligrafia Kurii Prowincjalnej Zakonu Pijarów 2009.

KaCZMAReK Antoni, Księgi metrykalne parafii Świętych Apostołów Szymona i Judy Tadeusza w Dmeninie, [t.] III: Liber baptisatorum, copulatorum et mortuorum parochialis in Dmenin 1755-1788, Dmenin: Wydawnictwo i Poligrafia Kurii Prowincjalnej Zakonu Pijarów 2012. 
KACZMAReK Antoni, Księgi metrykalne parafii Świętych Apostołów Szymona i Judy Tadeusza w Dmeninie, [t.] IV: Liber baptisatorum, copulatorum et mortuorum parochialis in Dmenin 1788 -1825, Dmenin: Wydawnictwo i Poligrafia Kurii Prowincjalnej Zakonu Pijarów 2012.

KrawczuK Wojciech, Miodunka Piotr, NabIalek Karol, Dzieje Wojnicza od XVI do XVIII wieku, Wojnicz: Towarzystwo Przyjaciół Ziemi Wojnickiej 2009.

KrogUlSKi Mariusz Lesław, Rodowody mieszczan wojnickich, t. 1-4, Wojnicz: Towarzystwo Przyjaciół Ziemi Wojnickiej 2006-2011.

Księga chrztów parafii radzionkowskiej z lat 1811-1850, oprac. Zbigniew Kwaśny („Acta Universitatis Wratislaviensis", Historia, nr 131), Wrocław: Wydawnictwo Uniwersytetu Wrocławskiego 1997.

Księgi metrykalne kościołów radomskich z lat 1591-1795, Seria A: Metryki chrztów, t. I: Kościót św. Jana Chrzciciela 1597-1620, red. Andrzej Szymanek, Radom: Radomskie Towarzystwo Naukowe 2004.

Księgi metrykalne kościołów radomskich z lat 1591-1795, Seria A: Metryki chrztów, t. II: Kościót św. Jana Chrzciciela 1621-1636, red. Sebastian Piątkowski, Radom: Radomskie Towarzystwo Naukowe 2001.

Księgi metrykalne kościołów radomskich z lat 1591-1795, Seria A: Metryki chrztów, t. III: Kościót św. Jana Chrzciciela 1637-1660, red. Sebastian Piątkowski, Radom: Radomskie Towarzystwo Naukowe 2002.

Księgi metrykalne kościołów radomskich z lat 1591-1795, Seria A: Metryki chrztów, t. IV: Kościót św. Wactawa 1636-1696, red. Sebastian Piątkowski, Radom: Radomskie Towarzystwo Naukowe 2002.

Księgi metrykalne kościołów radomskich z lat 1591-1795, Seria A: Metryki chrztów, t. V: Kościót św. Wacława 1697-1712, red. Sebastian Piątkowski, Radom: Radomskie Towarzystwo Naukowe 2003

Księgi metrykalne kościołów radomskich z lat 1591-1795, Seria A: Metryki chrztów, t. VI: Kościót św. Jana Chrzciciela 1661-1677, red. Sebastian Piątkowski, Radom: Radomskie Towarzystwo Naukowe 2003.

Księgi metrykalne kościołów radomskich z lat 1591-1795, Seria A: Metryki chrztów, t. VII: Kościót św. Jana Chrzciciela 1678-1712, red. Dariusz Kupisz, Radom: Radomskie Towarzystwo Naukowe 2010.

Księgi metrykalne kościołów radomskich z lat 1591-1795, Seria A: Metryki chrztów, t. VIII: Kościót św. Jana Chrzciciela 1713-1745, red. Dariusz Kupisz, Radom: Radomskie Towarzystwo Naukowe 2012.

Księgi metrykalne kościołów radomskich z lat 1591-1795, Seria A: Metryki chrztów, t. IX: Kościót św. Jana Chrzciciela 1746-1771, red. Dariusz Kupisz, Radom: Radomskie Towarzystwo Naukowe 2012.

Księgi metrykalne kościołów radomskich z lat 1591-1795, Seria A: Metryki chrztów, t. X: Kościót św. Jana Chrzciciela 1772-1795, red. Dariusz Kupisz, Radom: Radomskie Towarzystwo Naukowe 2012.

Księgi metrykalne kościołów radomskich z lat 1591-1795, Seria A: Metryki chrztów, t. XI: Kościót św. Wacława 1713-1744, red. Dariusz Kupisz, Radom: Radomskie Towarzystwo Naukowe 2014.

Księgi metrykalne kościołów radomskich z lat 1591-1795, Seria A: Metryki chrztów, t. XII: Kościót św. Wactawa 1745-1783, red. Dariusz Kupisz, Radom: Radomskie Towarzystwo Naukowe 2013. 
Księgi metrykalne kościolów radomskich z lat 1591-1795, Seria A: Metryki chrztów, t. XIII: Kościót św. Wacława 1784-1795, red. Dariusz Kupisz, Radom: Radomskie Towarzystwo Naukowe 2014

KuKLo Cezary, Demografia Rzeczypospolitej przedrozbiorowej, Warszawa: Wydawnictwo DiG 2009.

KuKLo Cezary, Staropolska rejestracja metrykalna ślubów, chrztów i pogrzebów w warsztacie badawczym historyka, w: Człowiek w teatrze świata. Studia o historii i kulturze dedykowane Profesorowi Stanisławowi Grzybowskiemu z okazji osiemdziesiątych urodzin, red. Bożena Popiołek, (Prace Monograficzne, nr 578 - Uniwersytet Pedagogiczny im. Komisji Edukacji Narodowej w Krakowie), Kraków: Wydawnictwo Naukowe Uniwersytetu Pedagogicznego 2010.

KUMOR Bolesław, Reforma metryk kościelnych w zaborze austriackim (1775-1788), w: Studia $z$ historii gospodarczej i demografii historycznej. Prace ofiarowane profesorowi Stanistawowi Hoszowskiemu w 70. rocznice urodzin, red. Jan M. Małecki (Akademia Ekonomiczna w Krakowie. Zeszyty Naukowe, nr 70, 1974), Kraków: Akademia Ekonomiczna 1975.

Liber natorum [parafii Ochotnica Dolna], t. 1: 1784-1820, oprac. ks. Józef Urbaniak, Tarnów: Wydawnictwo Diecezji Tarnowskiej Biblos 2016.

Libri metrices ecclesiae parochialis Cmieloviensis, wyd. Jerzy Moniewski, t. 1, B1: Libri baptisatorum ecclesiae parochialis Cmieloviensis 1601-1667, Radom: Wydawnictwo Małonakładowe Jerzy Moniewski 2002.

Libri metrices ecclesiae parochialis Cmieloviensis, wyd. Jerzy Moniewski, t. 2, B2: Liber baptisatorum ecclesiae parochialis Cmieloviensis 1667-1695, Radom: Wydawnictwo Małonakładowe Jerzy Moniewski 2002.

Libri metrices ecclesiae parochialis Cmieloviensis, wyd. Jerzy Moniewski, t. 3, B3: Liber baptisatorum ecclesiae parochialis Cmieloviensis 1695-1719, Radom: Wydawnictwo Małonakładowe Jerzy Moniewski 2002.

Libri metrices ecclesiae parochialis Cmieloviensis, wyd. Jerzy Moniewski, t. 4, B4: Liber baptisatorum ecclesiae parochialis Cmieloviensis 1719-1739, Radom: Wydawnictwo Małonakładowe Jerzy Moniewski 2002.

Libri metrices ecclesiae parochialis Cmieloviensis, wyd. Jerzy Moniewski, t. 5, B5: Liber baptisatorum ecclesiae parochialis Cmieloviensis 1739-1758, Radom: Wydawnictwo Małonakładowe Jerzy Moniewski 2002.

Libri metrices ecclesiae parochialis Cmieloviensis, wyd. Jerzy Moniewski, t. 6, B6: Liber baptisatorum ecclesiae parochialis Cmieloviensis 1758-1797, P. 1: 1758-1770, Radom: Wydawnictwo Małonakładowe Jerzy Moniewski 2002.

Libri metrices ecclesiae parochialis Cmieloviensis, wyd. Jerzy Moniewski, t. 7, B7: P. 2: 17711791, Radom: Wydawnictwo Małonakładowe Jerzy Moniewski 2002.

Libri metrices ecclesiae parochialis Cmieloviensis, wyd. Jerzy Moniewski, t. 8, B8: P.3: 17921797, Radom: Wydawnictwo Małonakładowe Jerzy Moniewski 2002.

Libri metrices ecclesiae parochialis Cmieloviensis, wyd. Jerzy Moniewski, t. 9, B9: Liber baptisatorum ecclesiae parochialis Cmieloviensis 1797-1810 in rubricis, Radom: Wydawnictwo Małonakładowe Jerzy Moniewski 2002.

Libri metrices ecclesiae parochialis Cmieloviensis, wyd. Jerzy Moniewski, t. 22, B10: Libri baptisatorum ecclesiae parochialis Cmieloviensis 1811-1825 in rubricis, Radom: Wydawnictwo Małonakładowe Jerzy Moniewski 2005.

MAKAREwicz Stanisław, Cztery metryki Kazimierza Pułaskiego, „Archiwa, Biblioteki i Muzea Kościelne" 70 (1998), s. 237-245.

Metryki chrztów i ślubów od 1715 r. do 1765 r. oraz zgonów od 1763 r. do 1765 r. przechowywane $w$ archiwum parafii pod wezwaniem św. Aleksandra $w$ Suwatkach, t. 1-2, zebr. i przygot. 
do druku Stanisław Cieślukowski, kopie wykonał Lucjan Sobolewski, Białystok: Stanisław Cieślukowski 2016.

Metryka chrztów parafii św. Jakuba Apostoła w Tuchowie (1764-1776), oprac. Mariusz Lesław Krogulski (Materiały do dziejów Tuchowa, t. IV), Tuchów: Mała Poligrafia Redemptorystów 2014.

Metryki chrztów parafii pw. Św. Marii Magdaleny w Łęcznej z lat 1598-1624 i 1694-1695, oprac. Robert Jop (Fontes Lublinenses 8), Lublin: Archiwum Państwowe 2016.

Metryki kolegiaty św. Wawrzyńca w Wojniczu 1675-1784, t. I: Liber baptisatorum 1675-1712, wyd. Aleksandra Jaworska i Józef Szymański (Biblioteczka Historyczna - Towarzystwo Przyjaciół Ziemi Wojnickiej, t. 30-31), cz. 1-2, Wojnicz: Towarzystwo Przyjaciół Ziemi Wojnickiej 2006.

Metryki kolegiaty św. Wawrzyńca w Wojniczu 1675-1784, t. IV: Liber baptisatorum 1757-1776, wyd. Tomisław Giergiel i Józef Szymański (Biblioteczka Historyczna - Towarzystwo Przyjaciół Ziemi Wojnickiej, t. 34-35), cz. 1-2, Wojnicz: Towarzystwo Przyjaciół Ziemi Wojnickiej 2008.

Metryki kolegiaty św. Wawrzyńca w Wojniczu 1675-1784, t. VIII: Liber baptisatorum 1777-1784, wyd. Tomisław Giergiel, Józef Szymański i Barbara Trelińska (Biblioteczka Historyczna Towarzystwo Przyjaciół Ziemi Wojnickiej, t. 39), Wojnicz: Towarzystwo Przyjaciół Ziemi Wojnickiej 2017.

Metryki szlachty ewangelickiej parafii Skoki i Rejowiec - wypisy, wyd. Piotr Maciej Dziembowski, „Gens” 8 (2003/2004), s. 77-98.

Metryki szlachty parafii ewangelicko-reformowanej w Orzeszkowie - wypisy, wyd. Piotr Maciej Dziembowski, „Gens” 9 (2005/2006), s. 105-138.

Metryki szlachty parafii ewangelicko-reformowanej w Waszkowie - wypisy, wyd. Piotr Maciej Dziembowski, „Gens” 10 (2007/2008), s. 121-132.

Najstarsze metryki cieszyńskie. Księga metrykalna parafii pod wezwaniem Marii Magdaleny $w$ Cieszynie z lat 1628-1641, wyd. Idzi Panic (Acta Historica Silesiae Superioris, t. 18), Cieszyn: Starostwo Powiatowe, Polskie Towarzystwo Historyczne. Oddział 2006.

Nazwiska ochrzczonych parafii Ostróg 1599-1652, w: Wykazy osób z akt parafialnych diecezji tuckiej do 1945 roku, [t. 1], oprac. Waldemar W. Żurek, Lublin-Kielce: Wydawnictwo „Jedność" 2004.

NIEPIEKŁo Lech, Parafia Skibniew Podawce i jej mieszkańcy, t. 2: Metryki od XVII do XIX wieku, Skibniew-Podawce: Parafia rzymsko-katolicka p.w. św. Wojciecha w Skibniewie-Podawcach 2018.

NowAK Tomasz Andrzej, Księgi metrykalne parafii św. Lamberta w Radomsku, cz. 2: Ksiega ochrzczonych z lat 1739-1779 (Radomszczańska Biblioteczka Regionalna V), Radomsko: Polskie Towarzystwo Historyczne Oddział w Radomsku, Muzeum Regionalne im. Stanisława Sankowskiego w Radomsku 2013.

NowAK Tomasz Andrzej, Księgi metrykalne parafii św. Lamberta w Radomsku, cz. 3: Księga ochrzczonych z lat 1779-1796 (Radomszczańska Biblioteczka Regionalna VII), Radomsko: PolskieTowarzystwo Historyczne Oddział w Radomsku, Muzeum Regionalne im. Stanisława Sankowskiego w Radomsku 2014.

PIASECKI Edmund, Ludność parafii bejskiej (woj. kieleckie) w świetle ksiąg metrykalnych z XVIIIXX w. Studium demograficzne, Warszawa: Państwowe Wydawnictwo Naukowe 1990.

RACHWAE Piotr, Ksiegi metrykalne z czasów zaboru austriackiego $w$ archiwach parafialnych w Lubelskiem - regulacje prawne, stan zachowania, „Rocznik Lubelskiego Towarzystwa Genealogicznego" 6 (2014) (wyd. 2015), s. 306-325.

RACHWAE Piotr, Staropolskie księgi metrykalne $w$ archiwach parafialnych archidiecezji lubelskiej, „Kwartalnik Historii Kultury Materialnej” 63 (2015), z. 4, s. 585-601. 
Rachwat Piotr, Szady Bogumił, Obszar parafii jako czynnik źródtotwórczy rejestracji metrykalnej w dekanacie Kazimierz na przełomie XVIII i XIX wieku, „Przeszłość Demograficzna Polski" 38 (2016), nr 2, s. 35-72.

Rembalski Tomasz, Metryki chrztów parafii bruskiej z lat 1643-1649, „Acta Cassubiana” 7 (2005), s. 221-274.

SzKlarz-Habrowski Amadeusz, Księga ochrzczonych parafii Wniebowzięcia Najświętszej Maryi Panny we Mstowie (1719-1759), „Rocznik Towarzystwa Genealogicznego Ziemi Częstochowskiej" 2 (2011), s. 265-421.

TANDECKI Janusz, KOPIŃSKI Krzysztof, Edytorstwo źródeł historycznych, Warszawa: Wydawnictwo DiG 2014

WiLCZEWSKI Tadeusz, Metrykalna baza danych parafii Pręgowo 1711-1750, cz. 2: Źródła, Gdańsk: GALAN Gdańsk 2013.

Wilczewski Tadeusz, Metrykalna baza danych parafii Żukowo, 1608-1700, cz. 1: Źródła, Gdańsk: GALAN Gdańsk 2014.

Wilczewski Tadeusz, Metrykalna baza danych parafii Żukowo 1701-1750, cz. 2: Źródła, Gdańsk: GALAN Gdańsk 2015.

WilcZEwSKI Tadeusz, Mieszkańcy parafii Pręgowo w drugiej połowie XVII wieku, cz. 1-2: Źródła, Gdańsk: GALAN Gdańsk 2012-2016.

Wilczewski T., Mieszkańcy parafii Pręgowo $w$ drugiej połowie XVII wieku, cz. 3: Rodziny i osoby, Gdańsk: GALAN Gdańsk 2018.

WIŚNIEWSKI Krzysztof, Indeksacja akt stanu cywilnego w Oddziale w Puttusku Archiwum Państwowego m. st. Warszawy, „Rocznik Lubelskiego Towarzystwa Genealogicznego” 3 (2011), s. $187-191$

WLAŹLAK Władysław Piotr, Inwentarz ksiag metrykalnych Archiwum Archidiecezji Częstochowskiej im. ks. Walentego Patykiewicza, „Rocznik Towarzystwa Genealogicznego Ziemi Częstochowskiej” 1 (2011), s. 11-580.

\section{STAROPOLSKA LIBER BAPTISATORUM JAKO EDYCJA (STAN BADAŃ, METODY, POSTULATY)}

Streszczenie

Staropolskie metryki kościelne wymagają szerokich badań oraz edycji. Autor artykułu skupił się na Księgach ochrzczonych (Liber baptisatorum). W polskiej historiografii ogłoszono drukiem treść tego typu źródeł z szesnastu parafii. Stan badań jest daleko niewystarczający aby uzyskać szerszy obraz rejestracji metrykalnej w polskim Kościele. Artykuł dokonuje próby rekapitulacji dotychczasowych osiągnięć historiografii w zakresie rozwoju narzędzi badawczych wykorzystywanych w polskich edycjach Ksiąg ochrzczonych. Metody stosowane w tych edycjach są bardzo różnorodne i nie zawsze zgodne z potrzebami naukowymi. Analizy zawarte w artykule prowadzą do postawienia szeregu postulatów zarówno dotyczących zasad wydawania drukiem metryk chrztu, jak i zaspokojenia potrzeb badawczych związanych z badaniami nad stratyfikacją społeczną polskich parafii, dziejami i geografią Kościoła, demografią historyczną, czy nowożytną dyplomatyką.

Słowa kluczowe: rejestracja metrykalna; Ksiega ochrzczonych; edycja źródła; chrzest; edytorstwo źródeł historycznych; okres staropolski. 


\section{OLD POLISH LIBER BAPTISATORUM AS AN EDITION \\ (STATE OF RESEARCH, METHODS, POSTULATES)}

\section{S u m m a ry}

Old Polish church registers require extensive research and editing. The author of the article focused on the baptismal registers (Liber baptisatorum). In Polish historiography, the content of this type of sources from sixteen parishes has already been published. The state of research is far from sufficient to get a broader picture of record registration in the Polish Church. The article attempts to recapitulate the achievements of historiography to date in the field of development of research tools used in the Polish editions of the baptismal registers. The methods used in these editions are very diverse and not always in line with scientific needs. The analyzes contained in the article lead to a number of postulates both regarding the principles of issuing records of baptism and meeting research needs related to research on the social stratification of Polish parishes, the history and geography of the Church, historical demography, and modern diplomats.

Key words: church records of baptism; baptismal registers; source edition; baptism; editing historical sources; Old Polish period. 